\title{
SINGLE MOTHERS IN RUS SIA: HOUSEHOLD STRATEGIES FOR COPING WITH POVERTY
}

\author{
Michael Lokshin, \\ The World Bank \\ Kathleen Mullan Harris, \\ University of North Carolina at Chapel Hill \\ Barry Popkin ${ }^{1}$ \\ University of North Carolina at Chapel Hill
}

\begin{abstract}
This study presents trends in single parenthood in Russia and examines the factors that explain the living arrangements of single-mother households. The recent period of economic reforms in Russia has reduced government transfers, eliminated publicly subsidized preschool care programs, and worsened labor market opportunities for women. Our research shows that for the last decade the proportion of female-headed households has increased rapidly and these households have experienced an increasingly high poverty risk. Using seven rounds of data from the Russian Longitudinal Monitoring Survey (RLMS), we investigate the role that household living arrangements play in single-mother family income dynamics and the major factors that affect the income status of mother-only families in Russia. We find that enhanced earning power of the single parent as well as a higher level of child benefits increases the likelihood that the single parent family lives separately from other relatives. Increasingly, however, single mothers are choosing to co-reside with other relatives or adults to survive and raise children in times of economic stress and uncertainty.
\end{abstract}

Key words: poverty, single mothers, households, housing, Europe, Russia

\footnotetext{
${ }^{1}$ Data collection funding for the first round of the Russian Longitudinal Monitoring Survey (RLMS) was provide d by the W orld Bank and for the subseque nt rounds by the U.S. Ag ency for Intern ational De velopme nt. Additional funding for file creation has come from the National Institutes of Health (NIH) (1 RO1HD30880), for collaborative travel and research design work from the National Science Foundation (NSF) (SBR-9223326), and considerable support has come from the Carolina Population Center. This was a collaborative project of the University of North Carolina at Chapel Hill (UNC-CH), the Goskomstat, the Russian Center of Preventive Medicine (RCPM), the Russian Institute of Nutrition (RIN), and the Russian Institute of Sociology (ISRosAN). Key collaborators of the authors in this survey are: Barbara Entwisle, Lenore Kohlmeier, Thomas Mroz, Michael Swafford and Namvar Zohoori, US; Polina Kozyreva and Michael S. Kosolapov, ISRosAN; and Alexander Baturin, Russian Institute of Nutrition. For this study, Frances Dancy assisted with support in administrative matters, and Tom Swasey provided graphics support. All are thanked.
} 


\section{Introduction}

The economic and political reforms of the last decade have transformed the context in which Russian families raise and nurture children. The social safetynet that heretofore provided extensive free child care, maternal and infant health care, and many other subsidies, including the provision of child allowances and separate allowances for female-headed households no longer exists. The poverty rate has risen sharply (e.g., Mroz and Popkin, 1996; Lokshin and Popkin, 1999). Research on Russian poverty has shown that the structure of the poor population is very heterogeneous. Poverty spells are highly dynamic; the economy is rapidly changing and these changes affect various subgroups at different times (Lokshin and Popkin, 1999). Some subgroups of the population can cope better with the rapidly changing environment while others suffer disproportionally. In this context, single-parent households are of particular interest.

Single-parent households are especially vulnerable. For the single-mother family, the lack of a second provider and the mother's low eaming capacity place these families at increased risk of poverty (Prokofieva 1994). Almost 40 percent of single-mother families were below the povertyline in Russia in 1996 and the trend suggests that the proportion of poor single-mother households will continue to rise in the future. Recent longitudinal analysis finds single-parent families more likely to be persistently poor than other families and their spells of poverty are among the longest (Lokshin and Popkin, 1999).

The single-parent population is large and growing rapidly in Russia (Kremen 1990; Volkov 1993). This dramatic growth has attracted widespread social concern primarily because of the economic disadvantage associated with female headship (Bane 1986; Garfinkel and McLanahan 1986; Ellwood 1988; Duncan and Rodgers 1990; Prokofieva 1994) and, to a lesser extent, because of ideological concerns that center on the decline of the traditional nuclear family as a social institution (e.g., Popenoe, 1988).

Demographic patterns related to divorce and the growth of single-mother families are comparable in Russia with other Western countries. Divorce rates have been rising steadily since divorce laws were liberalized in 1965 (Imbrogno and Imbrogno, 1986). Remarriage rates are especially low for women (Pukhova, 1988), though have been increasing recently (Willekens and 
Scherbov, 1994) and nonmarital childbearing has been rising rapidly (Imbrogno and Imbrogno 1986; Darsky and Dworak, 1992; Jones and Grupp, 1987; Anderson 1984; Berliner 1983). Economic difficulties have exacerbated these patterns. Moreover, widowhood, elevated by a rising adult male mortality rate is high (Rimashevskaya, 1992; Bobadilla, Costello, and Mitchell, 1997). The consequence has been an increase in the proportion of families with children headed by divorced, unmarried, and widowed mothers (Volkov 1993).

The context of single parenthood in Russia is also subject to change with respect to the status of women (Ofer and Vinokur 1985; Jones and Grupp 1987). In the former Soviet Union, nearly 90 percent of working-age women were in the paid labor force and women's educational levels were higher than those of men (Berliner 1983; Lapidus 1985; Sanjian 1991). Many programs and laws were intended to guarantee legal equality with men and to insure women's rights and independence (e.g., legalized abortion) ( Lapidus 1982). Prior to the recent economic reforms, a comprehensive array of universal and specialized social welfare programs provided a relatively adequate and secure safety net for single and unmarried mothers and their children (Kremen 1990). Whether women will maintain their relatively high status and security within society is questionable once social and economic reforms set in.

This study examines the complex structures of household composition in which mother-only families are embedded. Female headship is largely defined in the literature by the number of parents in the family unit of reference (i.e., marital status), regardless of who else lives in the household (e.g., Hogan and Kitagawa 1985; McLanahan 1985; Krein and Beller 1988; Ermisch 1991). This missing information on other members who live in a household that is reported to be a household with single parent may provide important insights into strategies of family organization that may mitigate some of the social and economic hardships. Trost (1980) and Ericsson (1980) urged researchers to distinguish between a one-parent household and a one-parent family; however, most studies fail to make this distinction. The terms, household and family, are used interchangeably to describe the unit a woman is heading, whereas, particularly in the Russian context, a household unit may mean something quite different from a family unit with important social and economic implications. We define a household as a group of people who share a common household budget. The key difference between uses of the terms household and family is that household members need 
not be related (although most probably are) and that family is often defined only in terms of a nuclear unit, only that containing parents and children, devoid of the household living arrangements in which a family might be embedded. By remaining with husbands, even after divorce, or by moving in with parents or in-laws following divorce, or by sharing a household with other unrelated adults, single mothers can increase the social and economic resources available to them and their children. Such household living arrangements may facilitate household strategies to pool economic and other resources or to share child care responsibilities, thereby freeing the single parent to go to school or to work outside the home.

We expect household composition to be particularly complex in contemporary Russia. Housing shortages have historically made communal living arrangements the norm in Russia where the deficit of housing units relative to the number of families is very large (Morton 1987). Among mother-headed families counted in the 1989 Russia census (families containing women with children and no husband or a male partner), 13 percent lived in "extended" households (households where several families reside together). In a context of rapid economic and social change, the organization of household living arrangements may be especially dynamic and crucial to the well-being of mother-only families.

This study focuses on Russian households that contain a single-parent family, the majority of whom are female-headed in our data ${ }^{2}$. Using data from the Russian Longitudinal Monitoring Survey (RLMS), we investigate the role that household living arrangements play in single-mother family income dynamics and the major factors that affect the income status of mother-only families in Russia within a cross-sectional and longitudinal framework. We hypothesize that single mothers use the obvious advantages of living with other relatives or adults to survive and raise children in times of economic stress and uncertainty and that the effects of type of household living arrangement on income and poverty status are large for single mothers and their children.

Following a description of our data source, we demonstrate demographic trends in the main factors associated with the growth of single-mother families in Russia and then show the short-term

\footnotetext{
${ }^{2}$ Our data contain a small number of single-father families which permit us to analyze this family form separately in multivariate models, but the vast majority of single-parent families are mother-only families and thus our discussion focuses primarily on them.
} 
income dynamics and changes in the structure of households with single parents. The second part of the paper exploits the longitudinal data with an analysis of the single parent's choice of living arrangement. We conclude with a discussion of our major findings and the policy implications of our research.

\section{Data}

Data come from the Russian Longit udinal Monitoring Survey. RLMS is based on the first nationally representative sample of several thousand households across the Russian Federation. The survey comprises seven rounds conducted (I) in September 1992, (II) February 1993, (III) August 1993, (IV) November 1993, (V) December 1994, (VI) October 1995, and (VII) October 1996. Rounds I-IV surveyed 6,000-7,000 households with a sample that provides fewer than 20 primary sample units (PSU). In contrast, with a new sample with effectively 65 PSUs, the second phase consisting of rounds V, VI, and VII surveyed approximately 3000 households. The data are weighted across the rounds to ensure comparability and national representativeness. ${ }^{3}$

As a measure of household well-being we use total real monthly disposable household income based on June 1992 prices. It includes wages and salaries, social security transfers, private transfers, in-kind income, and income from home production. Calculations of in-kind income (i.e., production of the enterprise where household members work) take into account regional differences in prices on home-produced goods. We focus on total household income to define poverty in Russia on the basis of household welfare as in most countries.

The Russian poverty line was developed by using food prices to cost the age-gender specific food baskets necessary to meet dietaryintake levels that approximate the WHO/FAO Recommended Dietary Allowances. The food basket is created separately for children aged 0-6 and 7-17, adult males and females, female pensioners aged 55 and older, and male pensioners aged 60 and older.

${ }^{3}$ The weights and a range of issues related to the sample design and collection of these data are explained in depth in the documents found in the home page of the RLMS. The interested reader can also obtain the data sets free through the home page: www.cpc.unc.edu/projects/rlms/rlms_home.html. In addition, the reader can see Lokshin and Popkin,(1999), or Mroz and Popkin, (1996) for additional information on the sample and data set. 
Regional differences in prices were captured by using region-specific price information for monetary and in-kind income calculation. Economy of scale adjustment was also incorporated in our measurement of poverty.

\section{The prevalence of single parenthood in Russia}

Increases in divorce and non-marital childbearing, and an unbalanced sex ratio are the major demographic factors contributing to the growth of single parenthood in Russia. About two in three marriages in Russia currently end in divorce with the urban divorce rate more than twice as high as the rural rate (Table 1). The increase in rural divorces was higher than the change in the divorce rate in the urban areas. The 1996 period appears to be an anomaly. The decline in the divorce rate reflects a sharp decline in the number of marriages during this period.

Table 1 shows the marked decline in the Russian birth rate in the 1990s , particularly in urban areas. As overall fertility declined, the proportion of all births that were nonmarital doubled from about 10 percent in 1970-80 (when the crude birth rate (CBR) was 15/1,000) to about 20 percent in $1994(\mathrm{CBR}=10 / 1,000)$, and rose further to $23 \%$ by $1996(\mathrm{CBR}=9 / 1,000)$. By 1992, the rate of increase had slowed, and nonmarital childbearing increased by a third between 1992 and 1996, during the period of the RLMS. Data in Table 1 show that the increase in nonmarital childbearing that began in the early 1970s continues in present-day Russia with 23 percent of all children born to unmarried women in 1996. We observe a slightly higher incidence of out-of-wedlock births in rural Russia.

Historically, the excess female population was one of the main sources of single-mother families in Russia (Peers 1985). In the last several years the increasing death rate among Russian men has contributed to this imbalance (Bobadilla et al., 1997). Today Russian women account for more than 53 percent of the population and the gender imbalance is acute in some adult age cohorts.

The structure of households containing a single-parent family is quite heterogeneous. In our analysis we define five major types of households with single-parent families. Table 2 reports a cross-sectional distribution of households with a single mother through seven rounds of RLMS, 1992-96. 
The most common type of the household that contains a single-mother family consists of single mothers with children younger than 18 years old who do not live with others. The proportion of such households vary from 55.5 percent in 1992 to around 45 percent in 1994-96. The second most common household type is one in which the single parent lives with children and their grandparents (parents of the single mothers). The percentage of these households increased over the rounds of survey from 25.2 percent in 1992 to 32.2 percent by the end of 1996 .

A significant proportion of single-mother families live in households with grandparents and siblings. The majority of single parents in this type of household are young mothers. The next most frequent type is represented by families where the single mother lives with children who are younger and older than age 18. Somewhat older single mothers are found in this household composition category. The group "other" includes households with more complicated structures such as a singlemother family living with distant relatives or with non-relatives.

The structure of households would appear to be highly related to changes in the economic environment. Several studies (for example, Rendal and Speare 1995) demonstrate the contribution of extended-familyco-residence to poverty alleviation. Co-residence increases the household poverty threshold, but at a decreasing rate. Intra-household transfers are more efficient than inter-household transfers because of the economy of scale associated with household size. Available data allow us to examine changes in the household composition of families with single parents during the period of rapid economic and social transformations in Russia.

During the period covered by RLMS, we observe a decline in the proportion of single-parent families living separately from their relatives (55.5 percent of households with a single mother in 1992 and 43.8 percent in 1996) and an associated increase in the share of households where singlemother families live with other household members. The increase in co-residence occurred for the households consisting of a single mother, children, and grandparents and for single mothers with children living with the children's grandparents and her siblings.

These trends suggest that there can be advantages of living with relatives for the singlemother family during times of economic stress. Among these advantages are the benefits of larger families having smaller per capita living costs. Mroz and Popkin (1995) show the importance of economies of scale in Russia, although the adjustment to the poverty line for increased family size 
is lower than in the United States. A more important advantage to co-residence may be relatives' assistance with household and child care duties that may permit a single mother to work and ease the burden of her dual role.

Assistance with child care is especially significant because of a sharp decline in the number of state child care organizations over the last several years. According to the Russian State Committee on Statistics (Goskomstat 1997), the proportion of children in preschool organizations dropped by more than 40 percent from its peak of 70 percent of all children in 1989 . Not only has the number of kindergartens fallen, but the cost of kindergarten care has increased significantly. In the pre-transition period, subsidies from state and local government as well as subsidies from the enterprises where parents worked covered most of the family expenses on child care. Currently, almost all government subsidies have been eliminated and only a few firms pay for their employees' child care services. This generally affects low-income families in the Russian population and families with single mothers in particular. Such households cannot afford expensive child care services and have to cope with the problem on their own.

\section{Single-Mother Families and Poverty}

Households with single parents are among the poorest. Figure 1 shows the percentage of various types of Russian households with incomes below the regional poverty line for rounds of the RLMS. Poverty increases for all family types (especially pensioners), but for the entire period covered by the survey, households headed by single women with children have the highest poverty rates among Russian households. Data in the last two rounds of the survey show a growth in the poverty rates of single-parent households that reaches a level over 40 percent in 1995-1996. Table 3 shows that the economic status of single-parent families varies according to the composition of the households in which they live. Families of single women with children living alone are the poorest. In October 1996 almost half of such families had incomes below the poverty line. In every round of the survey, single-mother families living alone had one of the highest poverty rates among all households containing single-mother families. Single-mother families living in households with other members are relatively more economically secure. The lowest poverty rates are found for 
single-mother families who live with their parents and for single mothers who live with young children and children older 18. Presumably, older children contribute to household income with their own earnings. Single mothers who live with their siblings or other adult household members experience poverty rates nearly as high as single mothers who live alone. In spite of this withingroup variation, the economic status of households that contain single-mother families is systematically lower than that of two-parent families (shown in Figure 1). Table 4 presents data on the distribution of single-parent (all households that contain a single mother family) and all Russian households whose income was below the poverty line by the type of locality across time. In general, rural single mothers are most likely to be poor. For example, in 1996 almost 53 percent of rural single mother households were poor compared with 38 percent for the urban households and only 13 percent for the single parent households from metropolitan areas of Russia. While poverty rates among single-parent households are always higherthan the rates for all Russian households, in some years poverty rates in the general population approach those among single-parent households.

\section{Causes of economic well-being}

There are three major factors that can influence the income levels and economic stability of singlemother households (Garfinkel and McLanahan, 1986): (1) low earning capacity of single women with children; (2) inadequate level of support from the noncustodial fathers; and (3) low level of government support and benefits (transfers) for single-mother families. Next we explore the impact of each of these income components on the well-being of different types of single-mother households in Russia.

\section{Earnings of single mothers}

Labor force participation of single mothers in Russia is significantly higher than that of married women with children (Prokofieva, 1994). Eighty-one percent of single mothers living with children were in the labor force at the end of 1996 compared to 71 percent of mothers in nuclear families. Earnings are typically determined by a woman's level of education, work experience, and hours 
worked within the context of area of residence (which historically was not endogenous in the former Soviet Union where residential mobility was rare). For single parents, wage income represents the largest portion of total household income ( 42 percent for households with single parents); hence their characteristics are strongly correlated with their level of income.

Figure 2 shows the percentage of single-mother households with incomes below the poverty line by mother's education. While the economic situation has worsened for households with a single parent at any level of educational attainment, the decline in the household income has been sharper among the less educated. The most disadvantaged households are those in which the single mother has only a high school degree or less education. More than half of such households were poor in the last two rounds of survey. The gap in earnings between high and low educated mothers has been increasing over the period of the survey. In 1992 the difference between the proportion of poor families with the highest and lowest levels of education was 16.5 percent and in 1996 the gap reached 20.9 percent. This increase indicates that the earning potential of single mothers with low levels of education has been declining since 1992

While the educational levels of single mothers are not significantly different from those for the general female population in every round of the survey, there is considerable age-related variation. The education of younger single parents, women 18-30 years old, is consistently lower than the education of all women aged 18-30 in Russia. In contrast, the level of education of the older groups of single mothers is a little higher than the population average for the older ages. Early childbearing is associated with low education as young single mothers may cut their education short once they become pregnant. Older single mothers, on the other hand, have had the time to complete their education and may be selective of higher socioeconomic status as well, with more time to work and establish a career. In addition, older single mothers may have become single parents as a result of divorce, while younger single mothers are more likely to be heading their own families as a result of nonmarital childbearing, which we know is more selective of disadvantaged women than is divorce (McLanahan and Sandefur, 1994).

Government support and benefits, composition of household income 
The income composition of households with single parents and of the general Russian population is shown in Table 5. Income composition of households with a single mother is different from that of the general population and the importance of each income source varies with the household structure of single-mother families. The largest component of single-mother household income comes from wage income. This share is over 10 percent higher than it is for the general population.

The share of govemment and private transfers in the family budget is significantly higher for households with a single mother than for an average Russian household. In households where a single mother lives with children and grandparents, the proportion of income from pensions ishigher than the share of income from wages. At the same time, for households where a single parent and children live on their own, the share of income from pensions is almost seven times lower than the share on income from wages. A share of home production in the total household income for the households with single parent is lower than that share for the general population (12.9 v.s. 18.8 percent at the end of 1996). Overall, the proportion of transfers in family income declines with the increase of the number of adult members and pensioners in the household.

The proportionate share of child benefits in total family income has been increasing since 1992. Overall, child benefits contributed about 6 percent to the total family budget of single-parent households at the end of 1996. That number was as high as 8.9 percent for the single-mother family living alone, but for extended households, the percentage is much lower -2.8 percent. This type of government transfer is most beneficial for families with a small number of adults. For extended households, the contribution of child benefits is smaller than for families with one or two jobholders.

Transfers between relatives represent an important component of the one-parent family income (Cox, Zachary, and Jemenez, 1994 ). For all households with a single parent, about 11 percent of income came from this source. The reported share of economic help from relatives is much higher for single-mother families living alone than in extended households where several families live together.

Despite high divorce rates, alimony contributes only a small portion to total household income. Its share does not exceed 5 percent in any round of survey. That share is much smaller than the contribution of a father in an intact family and smaller than the money that a second working member in a nuclear family brings into the household budget. 


\section{Household strategies of co-residence}

We have documented the greater risks of poverty among households containing single-mother families and we have shown that mother-headed families living alone experience higher rates of poverty compared to single mothers families living within larger extended households. In a multivariate context we now examine the major factors that affect the single parent's decision to live alone or to co-reside with other household members.

\section{Theoretical framework}

Consider a one-period model in which a single-parent family has preferences over the consumption of the market goods, the quality of child care, and mothers' leisure. Assume that there are two residence states: the single-parent family can co-reside or live apart from other household members. Co-residence is associated with the smaller costs of transfers from the household to single-parent family, increasing returns to household production, economies through bulk discounts, and the help of other household members in child care. However, co-residence entails some costs, in particular, a loss of privacy. We assume that the household members take the residence decision of the single parent as a given. ${ }^{4}$ Assume also that the prior family formation, fertility decisions, and education of the household members are exogenous.

The single parent maximizes her utility function $U$ subject to budget and time constraints, and child care production function:

${ }^{4}$ We make this rather strong assumption in the absence of any information in the data about the members of the "old" household for the single-parent families who chose to separate from that household and live alone. However, Rosenweig and Wolpin (1994) showed that "parent's optimization problem must recognize that the parent cannot choose an alternative that is inferior from the daughter's perspective to an alternative that the daughter can freely choose." 


$$
\begin{aligned}
& \operatorname{Max} U=U(C, L, Q, i) \\
& \text { s.t. } C=E+W_{0} H-N Q_{p} p_{c c}-p_{h}(i) \\
& L+H=1 \\
& Q=Q_{p}+Q_{m}
\end{aligned}
$$

where $C$ is a consumption of a composite good, $L$ is a leisure time of a parent, $i$ is a residence state indicator (degree of privacy), $Q$ is a total quality of child care, $E$ is a nonwage family income which includes child benefits and alimony, $W_{o}$ is the parent's potential market wage, $H$ is the time spent by the parent in the labor market, $N$ is the number of children in the single-parent family, $p_{c c}$ is the price of child care, $Q_{p}$ is a per unit quality of formal child care, $Q_{m}$ is the quality of mother's child care, $p_{h}$ is the cost of housing that the family of a single parent faces which is a function of the chosen state of residence $i$, and utility $U$ is a twice-continuously differentiable, quasi-concave and increasing in $C, Q$, and $L$ function.

Assuming the particular type of residence, the parent solves the utility maximization problem and chooses the state with the highest utility: $V_{j}=\operatorname{Max}\left\{V_{i}\right\}, i=1,2$. The effects of the changes in the exogenous variables can be derived from the model for both states of residence.

It is possible to derive the effects of changes in exogenous variables on choice of states. In many instances, these effects cannot be signed a priori. However, assuming that $\mathrm{G}$ is a normal good, it can be shown that (1) An increase in offered wage $W_{o}$, and an increase in non-wage income $E$ raises the probability of living alone. (2) An increase in total available income will move singleparent preferences toward separate residence because the parent has more resources to offset the loss in the efficiency of intra-household transfers and loss in support of other household members in household and child care duties. (3) A presence of young children decreases the probability that the single parent would live in a non-communal household since young children are more time intensive, requiring greater care and attention, and correspondingly it is more costly to purchase such care outside the household. Other household members can ease the burden of child care for the single parent. Older children can potentially provide care for younger siblings, suggesting a positive influence of the presence of older children on the parent's choice to live alone. (4) An exogenous increase in the cost of housing $p_{h}$ decreases the probability of single parent families to live alone. Higher market prices of housing make it more attractive for single-parent families to rent their 
apartment and move in with other household members thereby increasing their total disposable income. At the same time, if housing is a public good (at least to some extent), the impact in per capita terms of a change in its price will be lower for larger households. (5) An increase in the price of child care $p_{c c}$ would decrease the probability of a single parent to live alone. Changes in the cost of child care influence the single-parent decision about the residence type through the budget constraint.

These predictions provide the basis for an empirical qualitative choice model. The empirical qualitative choice model estimates a reduced form specification in which the probability to choose the state of residence is a function of the exogenous variables.

\section{The empirical model}

Assuming that the unobserved indirect utility function $V_{i}$ can be approximated by a linear combination of the exogenous variables, the observed choice of the state of residence $D$ is:

$$
\begin{aligned}
& D=1 \text { if } V_{1}>V_{2} \text { i.e. }\left(X \beta_{1}+\varepsilon_{1}\right)-\left(X \beta_{2}+\varepsilon_{2}\right)>0=>X\left(\beta_{1}-\beta_{2}\right)>-\left(\varepsilon_{1}-\varepsilon_{2}\right) \\
& \text { or substituting } \tilde{\beta}=\left(\beta_{1}-\beta_{2}\right) \text { and } \widetilde{\varepsilon}=\varepsilon_{1}-\varepsilon_{2}=>X \tilde{\beta}>\widetilde{\varepsilon} \\
& D=0 \text { elsewhere }
\end{aligned}
$$

$D=1$ if the family of single parent lives with no other relatives, and $D=0$ if the family of single parent lives in extended household. To take into account possible idiosyncratic differences in household preferences we estimate our equation (2) on the sample of panel data. To estimate the model correctly we need to take care of the possible correlation between the error terms in the multiple observations of the same household and the correlation in the error terms because of the possible serial correlation in the dependent variable or the common effects of the unobserved macroshocks. In this case of the two-factor panel model, the structure of the error terms is as follows:

$$
\varepsilon_{i t}=v_{i}+v_{i t}+\alpha_{i} ; \quad i=1, \ldots, N ; \quad t=1,2,3
$$

where $v_{i}$ is a term that reflects household-specific effects, $v_{\mathrm{it}}$ is normally and identically distributed independent disturbances, and $\alpha_{\mathrm{t}}$ is a time-specific component of the error term. We control for the effects of time by introducing a set of dummy variables for each time period. Under the above assumptions about the error terms, equation (2) can be estimated by the random effect probit model. 
The set of exogenous variables used in the analysis includes the single parent's age, gender, level of education, and geographical place of family residence; the single parent's migration pattern (whether the single parent moves from her place of birth); number of children younger than seven years old; number of children 7-16 years old; the amount of child subsidies and alimony; "offered" wage of the single parent; proxy for the cost of housing; and proxy for the cost of child care.

Potential endogeneity of the size of the child subsidies could produce bias in our estimates. However, most of the government subsidies for children depend not on the housing characteristics of the families, but on the age of the children, and we take that factor into account in our estimates. Unmeasured characteristics of women and families that make single-parent families eligible for certain subsidies could bias our results.

The potential market wage of a parent is computed using a standard Mincer's type earning function (Mincer and Polacheck, 1974). The earning function equation is estimated on a set of explanatory variables that includes single parents' age and age squared, level of education, regional dummies, and a job seniority variable and the estimates are corrected for a selectivity bias using standard Heckman (1978) method. The potential market wage for each single parent is predicted based on the estimations of the separate models for men and women who received wages in the last month of the survey. The predicted wage is then substituted in the probit equation (2) estimated on the sample of single-parent households.

There is no information in the data about the housing costs that the particular household faces. Because of that, we approximate this cost by estimating the average household expenditure on rent in each 160 population points of the survey. The costs of housing were estimated separately for the households that rent and own their housing. This proxy for the cost of housing was then imputed for the sample of the households with a single parent.

We use the same method to estimate the cost of child care, similar to Blau and Robins (1988). An average real household expenditure on child care was calculated for each population point and then was imputed for every household with a single parent who lives in that population point.

Results of the estimation of model (2) are presented in the Table 6. Income effects are found to be important determinants of the single parent's decision to live alone or to cohabit with other 
relatives or adults. An increase in the single parent's potential wage increases the probability that the single-parent family lives alone in a separate household. A higher level of child benefits also increases the likelihood that the single parent lives alone. Clearly, more income provides the single parent with more resources to pay for separate housing costs and for other costs of care for the children. Younger parents are less likely to choose a separate residence, although the effect of age on the probability of living alone decreases with the age of the parent. Younger parents are probably more dependent on their parents and other family members as they have not had as much time to establish their social and economic independence as adults.

Single fathers are significantly more likely to live within an extended household, suggesting that single fathers are more likely to rely on other female household members to help care for and raise children and/or engage in related home production activities, especially while they work. The educational level of the single parent does not appear to have a significant influence on the choice of residence.

The number of older children in the family increases the likelihood that single parents choose to live on their own. Older children can contribute to the household budget through their work and care of younger siblings to the family. Single parents who live in metropolitan areas of Russia are more likely to co-reside with other relatives compared to rural single-parent families. The large metropolitan areas (Moscow, St. Petersburg) have shortages in housing stock which makes it difficult for single parents to live alone. In addition, housing stock costs more and female labor force participation is higher because of increased employment options, necessitating co-residence with others in order to work.

Community housing costs and child care costs do not show significant effects on the singleparent families living arrangement decisions, although they operate according to theoretical expectations. Such community effects are probably not exerting the kinds of influence we might expect because the housing market in Russia is not developed to the degree that people can freely rent out their houses or apartments and the decision of a single parent to move in with other household members does not automatically bring into the family additional income from rent. In addition, because child care facilities posed no costs to Russian women prior to the social reforms and alternate private child care services never developed, there has been a slow transition toa private 
market for child care services.

The time effects show that single-parent families living alone in independent households has become less prevalent over time since the economic reforms were established. Relative to the most recent round of the RLMS, single parents were more likely to live alone in earlier time periods. Thus,

as the Russian economy has deteriorated, wages have declined, unemployment has increased, and social welfare policies have been dissolved or cut back, co-residence has become a necessary and more common choice of living arrangement strategies for survival of most vulnerable family groups.

\section{Conclusion}

Our study has documented high poverty risks among single-mother families in Russia following the social and economic reforms of the late 1980s and 90s. Single parenthood is an increasingly common family form in Russia as a result of demographic change in marriage and childbearing patterns. During the pre-transition period, single mothers and their children were relatively protected from poverty through government assistance with income support, subsidized child care, and full employment guarantees. As a result of the economic reforms, women have become more vulnerable in general, and single mothers especially vulnerable in particular. The loss of government social welfare, the lack of affordable child care, the decline in labor market opportunities and gender equity in earnings has eroded family stability in Russia and has left single mothers at considerable risk of poverty.

The recent data from RLMS reveals this vulnerability. The economic status of single-mother households is one of the lowest relative to other households in Russia. Young single mothers and their children are among the poorest in the population. To cope with economic hardship many single mothers choose co-reside with relatives and other adults. We show that almost half of all single mothers live in extended households with parents, adult siblings, or other adult relatives for the advantages of economies of scale with respect to household size, the efficiency of inter-household transfers relative to intra-household transfers, and the sharing of domestic duties and child care duties. The other half of the single-mother families live in independent residences and face greater economic insecurity as their earnings alone must make up a larger share of total household income. 
Private and state transfers represent only a small share of total income of single-mother households, although this proportion has been increasing over the last four years. Help from relatives is an important component of single-mother household income, and this help is more efficient and productive when single mothers co-reside with relatives.

Our findings about living arrangement decisions confirm the predictions of the qualitative choice model. The economic hardships that the single-parent family experiences during the period of transition to the market economy has a negative impact on family income which, in turn, makes it more likely that the single-parent family lives in an extended household. Our estimations suggest that this pattern of co-residence among single-parent families will increase in the future. Further declines in real wages are expected to increase the number of single parents who prefer to co-reside with other relatives or adults directly through the decline in parents' earnings and indirectly through the decrease in alimony support from the former spouse. The prevalence of co-residence will also increase as child support subsidies wane.

While the proportion of single parent households residing in rural areas is lower than the proportion in urban areas of Russia, these households experience the highest poverty rates and are more likely to live alone (Table 4). Rural single-parent households, the majority of whom are singlemother families, may not have as much access to extended family and other forms of co-residence in the rural areas of Russia.

The current situation in Russia indicates a considerable worsening of the economy and a rapid diminishment of the government's ability to provide transfers. Our results suggest a continued deterioration of an already poor situation for single parents and their children, who represent a growing number of households in contemporary Russia. Nearly one-quarter of all households contain a single-parent family. While single parents are likely to accelerate their movement into extended families, poverty for them and their children will continue to grow considerably. 


\section{References}

Anderson, Barbara A. 1984. "Family and fertility in Russian and Soviet censuses." Population Studies Center Research Report no. 84-64. University of Michigan, Ann Arbor.

Bane, Mary Jo. 1986. "Household composition and poverty." In Sheldon H. Danziger and Daniel H. Weinberg (eds.), Fighting Poverty: What Works and What Doesn't. Harvard University Press, Cambridge, MA, 209-231.

Berliner, Joseph S. 1983. "Education, labor-force participation, and fertility in the USSR." Journal of Comparative Economics 1983:131-157.

Blau, David and Philip K. Robins. 1988. "Childcare cost and family labor supply." Review of Economics and Statistics 70:374-381.

Blau, Francine D. and Lawrence W.. Kahn. 1995. "Wage structure and gender earnings differentials: and international comparison." Journal of Human Resources 63:S29-63.

Bobadilla, José-Luis, Christine A. Costello, and Faith Mitchell, eds. 1997. Premature Death in the New Independent States. Committee on Population, Commission on Behavioral and Social Sciences and Education, National Research Council. Washington DC: Academy Press.

Cox, Donald., Zekeriya, Eser, and Emmanuel Jimenez. 1997. "Family safety nets during economic transitions." In Poverty in Russia: Public Policy and Private Resopnces, Jeni Klugman (ed.). EDI Development Studies. The World Bank. Washington, DC, 211-249.

Darsky, L., and Dworak, N., 1992. "Fertility, Contraception and Induced Abortion in Russia: Some Recent Measures." Paper presented at the Meeting on Population Activities in the NIS, Office of Population, USAID.

Duncan, Greg J. and Willard Rodgers. 1990. "Lone-parent families and their economic problems: Transitory or persistent?" In Lone-Parent Families: The Economic Challenge, Elizabeth Duskin (ed.). OECD Social Policy Studies no. 8. Paris: Organisation for Economic Co-operation and Development, 43-68.

Ellwood, David T. 1988. Poor Support: Poverty in the American Family. New York: Basic Books.

Ericsson, Margareta. 1980. "Some empirical and theoretical reflections on the conditions of the non-guardian." Journal of Comparative Family Studies 11:87-114.

Ermisch, John F. 1991. Lone Parenthood: an Economic Analysis. Occasional Papers (National Institute of Economic and Social Research) no. 44. Cambridge: Cambridge University Press.

Garfinkel, Irwin. and Sara S.McLanahan. 1986. Single Mothers and Their Children: A New American Dilemma. The Changing Domestic Priorities Series. Washington, DC: The Urban Institute Press.

Goskomstat [State Committee on Statistics]. 1997. "Russian statistical annual report." State Statistical Office Press, Moscow. [in Russian]

Heckman, James J. 1979. "Sample selection bias as a specification error." Econometrica 47:153-161.

Hogan, Dennis P. and Evelyn M. Kitagawa. 1985. "The impact of social status, family structure, and neighborhood on the fertility of black adolescents." American Journal of Sociology 90:825-55.

Imbrogno, Salvatore and N. I. Imbrogno. 1986. "Marriage and family in the USSR: Changes are emerging." Social Casework 67:90-100.

Jones, Ellen and Fred W. Grupp. 1987. Modernization, Value Change, and Fertility in the Soviet Union. Soviet and East European Studies. Cambridge, England: Cambridge University Press.

Krein, Sheila Fitzgerald and Andrea H. Beller. 1988. "Educational attainment of children from single-parent families: Differences by exposure, gender, and race." Demography 25:221-34.

Kremen, Eleanor. 1990. "Socialism: An escape from poverty? Women in European Russia." Pp. 157-82 in 
Gertrude Schaffner Goldberg \& Eleanor Kremen. (eds.), The Feminization of Poverty: Only in America? Contributions in Women's Studies, no. 117. New York: Praeger.

Lapidus, Gail Warshofsky (ed.). 1982. Women, Work, and the Family in the Soviet Union, Vladimir Talmy, trans. Armonk, NY: M.E. Sharpe.

Lapidus, Gail Warshofsky. 1985. "The Soviet Union." In Jennie Farley (ed.) Women Workers in Fifteen Countries. Essays in Honor of Alice HansonCook. Cornell International Industrial and Labor Relations Report no. 11. Ithaca, NY: ILR Press.

Lokshin, Michael and Popkin, Barry M. 1999. "Emerging Underclass in Russia: Income Dynamics, 1992-1996" Journal of Economic Development and Cultural Change Vol.47, 4:803:829

London, Rebecca A. 1998. "Trends in single mothers' living arrangements from 1970 to 1995: Correcting the Current Population Survey." Demography 35:125-131.

Manski, Charles F. 1989. "Anatomy of the selection problem." Journal of Human Resourœs 24:343-360.

McLanahan, Sara S. 1985. "Family structure and the reproduction of poverty." American Journal of Sociology 90:873-901.

McLanahan, Sara S. and Gary Sandefur. 1994. Growing Up with a Single Parent: What Hurts, What Helps Cambridge, MA: Harvard University Press.

Mincer, Jacob, and Solomon Polachek. 1974. "Family investment in human capital: earnings of women." Journal of Political Economy 82 (Suppl.):S76-S108

Morton, H. W. 1987. "Housing quality and housing classes in the Soviet Union." Pp. 95-115 in Horst Herlemann (ed.), Quality of Life in the Soviet Union. A Westview Special Study. Boulder, CO: Westview Press.

Mroz, Thomas and Barry M. Popkin (1995). "Poverty and the Economic Transitionin the Russian Federation." Economic Development and Cultural Change 44:1-31.

Ofer, Gur and Aaron Vinokur. 1985. "Work and family roles of Soviet women: Historical trends and crosssection analysis." Journal of Labor Economics 3:S328-S354.

Peers, Jo. (1985). "Working by hand and womb--Soviet women and the demographic crisis." In Barbara.Holland, (ed.), Soviet Sisterhood British Feminists on Women in Russia. Bloomington: Indiana University Press.

Popenoe, David. 1988. Disturbing the Nest: Family Change and Decline in Modern Societies. Social Institutions and Social Change. New York: Aldine de Gruyter.

Prokofieva, L. M. 1994 "The basic indices of living standards for families of different demographic type." In Bednost? Vzgliad uchenykh na problemu [Poverty: point of view of scientists, M. A. Mozhina (ed. ). Demografiia i sotsiologiia, vol.10. Moscow: Rossiiskaia akademiianauk, In-t sotsial?no-ekon.problem narodonaseleniia, ISEPS Russian Academy of Sciences [-in Russian-]

Pukhova, Zoia Pavlovna. 1988. For a Better Life and More Good Will. Moscow: Novosti Press.

Rendal Michael S. and Alden Speare Jr. 1995. "Elderly poverty alleviation through living with family," Journal of Population Economics, 8:383-405

Rimashevskaya, Natalya M. 1992. "Taganrog studies: Family well-being, conditions, standards, way and quality of life of the population of Russia." Unpublished manuscript, Institute of the Russian Academy of Sciences.[in Russian]

Rosenzweig, Mark R. and Kenneth I. Wolpin. 1994. "Parental and public transfers to young women and their children." American Economic Review 84:1195-1212.

Sanjian, Andrea Stevenson. 1991. "Social problems, political issues: marriage and divorce in the USSR." Soviet Studies 43:629-49. 
Trost, Jan. 1980. "The concept of one-parent family." Journal of Comparative Family Studies 11:129-38. Volkov, A. (Ed), 1993. "Demographicheskie perspektivy Rossii [Demographic prospects of Russia]." Goskomstat od Russia,Moscow [-in Russian-]. 
Table 1: Divorce and birth rates in Russian Federation. (1970-96)

\begin{tabular}{|c|c|c|c|c|c|c|c|c|c|c|}
\hline & 1970 & 1980 & 1985 & 1990 & 1991 & 1992 & 1993 & 1994 & 1995 & 1996 \\
\hline Divorce rate(divorces/1000) & 3.0 & 4.2 & 4.0 & 3.8 & 4.0 & 4.3 & 4.5 & 4.6 & 4.5 & 3.8 \\
\hline urban & 4.2 & 5.1 & 4.7 & 4.4 & 4.6 & 5.0 & 5.2 & 5.3 & 5.2 & 4.4 \\
\hline rural & 1.2 & 2.2 & 2.2 & 2.1 & 2.3 & 2.4 & 2.6 & 2.7 & 2.8 & 2.2 \\
\hline Birth rate (births/1000) & 14.6 & 15.9 & 16.6 & 13.4 & 12.1 & 10.7 & 9.4 & 9.5 & 9.3 & 8.9 \\
\hline urban & 14.8 & 15.8 & 16.1 & 12.7 & 11.2 & 9.8 & 8.6 & 8.9 & 8.6 & 8.3 \\
\hline rural & 14.3 & 16.1 & 17.8 & 15.5 & 14.5 & 13.2 & 11.5 & 11.2 & 10.9 & 10.4 \\
\hline $\begin{array}{l}\text { Percentage of out of wedlock } \\
\text { births }\end{array}$ & 10.6 & 10.8 & 12.0 & 14.6 & 16.0 & 17.2 & 18.2 & 19.6 & 21.1 & 23.0 \\
\hline urban & 9.6 & 9.6 & 11.3 & 13.8 & 15.5 & 16.7 & 18.1 & 19.5 & 21.1 & 22.8 \\
\hline rural & 12.3 & 13.4 & 13.6 & 16.5 & 17.3 & 18.1 & 18.4 & 19.8 & 21.3 & 23.5 \\
\hline
\end{tabular}

Source: Russian Statistical Annual Report, Goskomstat Russia, Moscow 1997

Table 2: Cross-sectional distribution of single mother families by household type.

\begin{tabular}{|c|c|c|c|c|c|c|c|}
\hline \multirow[b]{2}{*}{ Type of family } & \multicolumn{7}{|c|}{ Rounds of RLMS } \\
\hline & $9 / 92$ & $2 / 93$ & $8 / 93$ & $11 / 93$ & $12 / 94$ & $10 / 95$ & $10 / 96$ \\
\hline Single mother & 55.5 & 51.8 & 51.9 & 51.1 & 43.3 & 45.8 & 43.8 \\
\hline Single mother and grandparent & 25.2 & 27.3 & 26.8 & 28.1 & 32.7 & 29.4 & 32.2 \\
\hline $\begin{array}{l}\text { Single mother with grandparents and } \\
\text { siblings }\end{array}$ & 7.2 & 8.3 & 9.0 & 7.2 & 8.7 & 9.1 & 9.8 \\
\hline Single mother and mixed-age children & 8.0 & 8.5 & 8.9 & 10.7 & 8.0 & 8.4 & 8.2 \\
\hline Other & 4.1 & 4.1 & 3.4 & 2.9 & 7.3 & 7.3 & 6.0 \\
\hline Total & 100.0 & 100.0 & 100.0 & 100.0 & 100.0 & 100.0 & 100.0 \\
\hline $\begin{array}{l}\text { Proportion of all Russian households } \\
\text { with a single parent }\end{array}$ & 9.50 & 8.90 & 8.80 & 8.80 & 7.90 & 7.90 & 8.50 \\
\hline
\end{tabular}


Table 3: Percentage of households with a single-parent family below regional poverty line.

\begin{tabular}{|c|c|c|c|c|c|c|c|}
\hline & \multicolumn{7}{|c|}{ Rounds of RLMS } \\
\hline & $9 / 92$ & $2 / 93$ & $8 / 93$ & $11 / 93$ & $12 / 94$ & $10 / 95$ & $10 / 96$ \\
\hline Single parent & 23.1 & 39.6 & 20.5 & 23.0 & 26.7 & 44.9 & 47.8 \\
\hline Single parent and grandparent & 16.0 & 28.6 & 14.5 & 11.9 & 18.3 & 33.3 & 29.9 \\
\hline Single parent with grandparents and siblings ${ }^{1}$ & 22.5 & 25.0 & 16.7 & 15.6 & 20.8 & 45.8 & 46.4 \\
\hline Single parent and mixed-age children ${ }^{2}$ & 31.8 & 31.7 & 18.2 & 19.6 & 12.5 & 36.0 & 24.0 \\
\hline Other & 13.6 & 20.0 & 23.1 & 0.0 & 22.7 & 42.9 & 44.4 \\
\hline Total & 21.6 & 33.9 & 18.4 & 18.5 & 22.1 & 40.7 & 39.8 \\
\hline
\end{tabular}

${ }^{1}$ This categ ory includes fa milies with single parent living with siblings and one or two par ents

${ }^{2}$ Single parent with children younger and older than 18 years

Table 4: Percentage of single parent households with income below poverty line by type residence.

\begin{tabular}{|c|c|c|c|c|c|c|c|}
\hline \multirow[t]{2}{*}{ Residence } & \multicolumn{7}{|c|}{ Rounds of RLMS } \\
\hline & $9 / 92$ & $2 / 93$ & $8 / 93$ & $11 / 93$ & $12 / 94$ & $10 / 95$ & $10 / 96$ \\
\hline & \multicolumn{7}{|c|}{ Single-parent households } \\
\hline Metropolitan ${ }^{1}$ & 16.9 & 42.5 & 17.7 & 14.7 & 6.1 & 29.6 & 13.0 \\
\hline Urban $^{2}$ & 21.0 & 30.4 & 18.3 & 19.4 & 24.2 & 38.4 & 38.3 \\
\hline \multirow[t]{2}{*}{ Rural } & 28.4 & 38.8 & 18.9 & 18.6 & 24.1 & 53.3 & 52.8 \\
\hline & \multicolumn{7}{|c|}{ General population } \\
\hline Metropolitan & 10.3 & 21.5 & 7.7 & 9.4 & 10.4 & 16.1 & 11.4 \\
\hline Urban & 11.5 & 18.1 & 10.1 & 12.7 & 16.0 & 28.5 & 32.3 \\
\hline Rural & 10.4 & 16.6 & 9.9 & 15.4 & 23.4 & 36.5 & 47.9 \\
\hline
\end{tabular}

${ }^{1}$ This category includes households from Moscow and St. Petersburg

${ }^{2}$ This category includes households from urban areas of Russia excluding metropolitan areas 
Table 5: The main components of single-parent household income in 1996

\begin{tabular}{|c|c|c|c|c|c|c|c|c|}
\hline & \multicolumn{8}{|c|}{ Shares of total household income } \\
\hline & Salaries & $\begin{array}{c}\text { Child } \\
\text { Benefits }\end{array}$ & Alimonies & $\begin{array}{c}\text { Home } \\
\text { Production }\end{array}$ & $\begin{array}{l}\text { Family } \\
\text { transfers }\end{array}$ & $\begin{array}{l}\text { NGO } \\
\text { help }\end{array}$ & Pensions & $\begin{array}{c}\text { Other } \\
\text { sources }\end{array}$ \\
\hline All Russian households & 38.6 & 2.4 & 0.5 & 18.8 & 9.6 & 0.8 & 23.2 & 6.1 \\
\hline $\begin{array}{l}\text { All households with single } \\
\text { parent }\end{array}$ & 42.1 & 6.3 & 3.9 & 12.9 & 11.3 & 0.9 & 15.8 & 6.9 \\
\hline Single pare nt only & 42.1 & 8.9 & 5.5 & 12.3 & 15.8 & 1.2 & 6.7 & 7.5 \\
\hline $\begin{array}{l}\text { Single parent with grand } \\
\text { parents }\end{array}$ & 39.3 & 4.5 & 2.3 & 13.5 & 6.6 & 0.3 & 28.6 & 5.0 \\
\hline $\begin{array}{l}\text { Single pare nt with } \\
\text { grandparents and siblings }\end{array}$ & 46.2 & 4.6 & 3.9 & 17.0 & 11.3 & 0.0 & 9.9 & 7.3 \\
\hline $\begin{array}{l}\text { Single parent and mixed - } \\
\text { age children }\end{array}$ & 49.4 & 2.8 & 1.2 & 8.2 & 4.1 & 3.5 & 17.6 & 13.3 \\
\hline $\begin{array}{l}\text { Other households with } \\
\text { single parent }\end{array}$ & 43.1 & 2.8 & 3.9 & 13.4 & 11.5 & 0.4 & 20.5 & 4.5 \\
\hline
\end{tabular}


Table 6: Random effect probit estimation of probability for single-parent family to live alone

\begin{tabular}{|c|c|c|}
\hline & Coefficient & Standard error \\
\hline Offered wage/1000 & $0.152 * *$ & 0.074 \\
\hline Child benefits and alimony/1000 & $0.108 * *$ & 0.043 \\
\hline \multicolumn{3}{|l|}{ Individual characteristics } \\
\hline Mother's age & $0.082(* * *)$ & 0.055 \\
\hline Mother's age ${ }^{2}$ & $-0.001(* * *)$ & 0.001 \\
\hline Male & $-0.975 * * *$ & 0.304 \\
\hline Female & Refer & \\
\hline High school & 0.242 & 0.161 \\
\hline Technical/vocational & 0.147 & 0.147 \\
\hline University & Refer & \\
\hline \multicolumn{3}{|l|}{ Household characteristics } \\
\hline No. of children younger than 7 years & 0.085 & 0.119 \\
\hline No. of children 7 years and older & $0.160 *$ & 0.098 \\
\hline Lives in different place than birth place & -0.048 & 0.083 \\
\hline Lives in birth place & Refer & \\
\hline Metropolitan area & $-0.460 *$ & 0.267 \\
\hline Other urban areas & 0.039 & 0.171 \\
\hline Rural areas & Refer & \\
\hline \multicolumn{3}{|l|}{ Characteristics of population points } \\
\hline Average rent expenditure & -0.041 & 0.027 \\
\hline Average expenditure on utilities (own housing) & -0.017 & 0.049 \\
\hline Average expenditure on child care & -0.079 & 0.188 \\
\hline \multicolumn{3}{|l|}{ Time dummies } \\
\hline Round V & $0.129 * *$ & 0.069 \\
\hline Round VI & $0.130 *$ & 0.059 \\
\hline Round V II & Refer & \\
\hline Constant & $-2.741 * * *$ & 1.013 \\
\hline
\end{tabular}

* Significant with 90 percen t probability

** $\quad$ Significant with 95 percent probability 


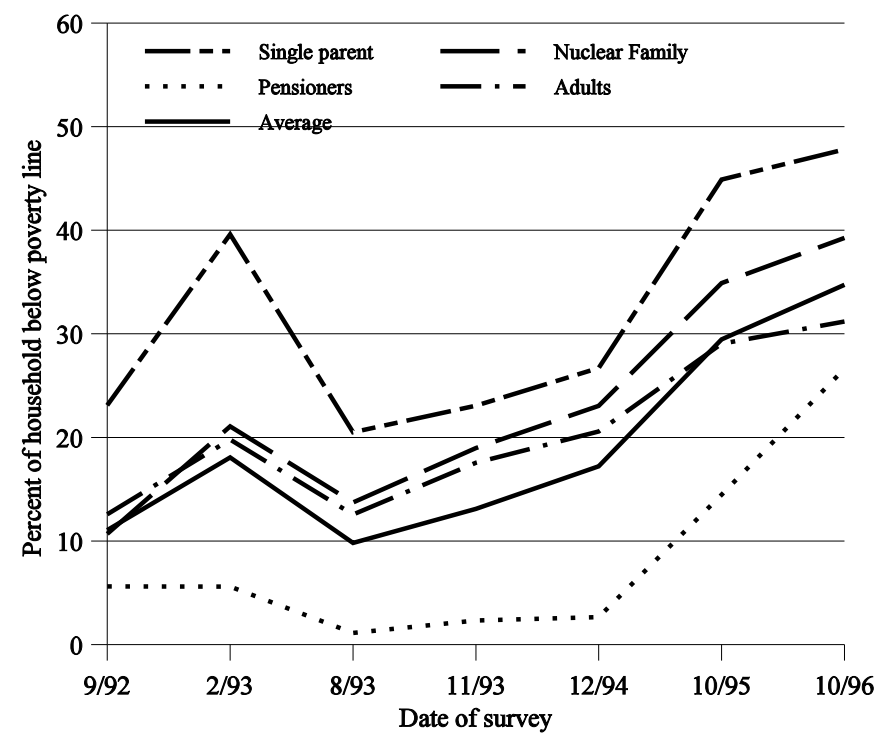

Figure 1: Percentage of Russian households with income below poverty line by household type. Household types: Single parent — household with single mother and children; nuclear family - household consisting of two parents and children ; pensioners - household of one or two pensioners; adults - households consisting of several adults.

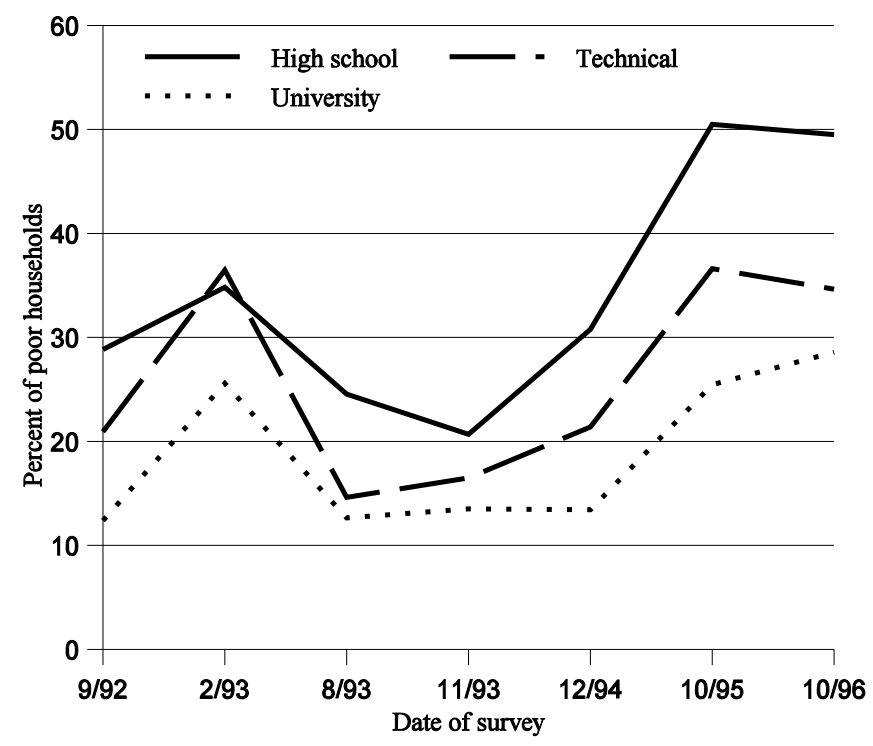

Figure 2: Cross-sectional distribution of Russian single-parent households with incomes below poverty line by the level of education of a single parent. RLMS Rounds I-VII, (9/92-10/96) 